\title{
I. On a form of Daniell cell convenient as a standard of electromotive force
}

\author{
Oliver J. Lodge D.Sc.
}

To cite this article: Oliver J. Lodge D.Sc. (1878) I. On a form of Daniell cell convenient as a standard of electromotive force , Philosophical Magazine Series 5, 5:28, 1-4, DOI: $10.1080 / 14786447808639377$

To link to this article: http://dx.doi.org/10.1080/14786447808639377

曲 Published online: 13 May 2009.

Submit your article to this journal $[\pi$

Џ Article views: 3

Q View related articles $\square$

Citing articles: 2 View citing articles $\square$ 
LONDON, EDINBURGH, AND DUBLIN

PHILOSOPHICAL MAGAZINE

AND

JOURNAL OF SCIENCE.

[FIFTH SERIES.]

$J A N U A R Y 1878$.

I. On a Form of Daniell Cell convenient as a Standard of Electromotive Force. By OLIver J. Lodge, D.Se.*

[Plate I.]

\begin{abstract}
A LTHOUGH a volt is the formal unit of electromotive A force, yet it happens in practice that differences of potential get stated as equal to so many Daniell cells more frequently than any thing else, showing that there is some decided convenience in this mode of statement, a convenience partly owing, no doubt, to the fact that a freshly set-up Daniell is a tolerably uniform and easily reproduced standard. An ordinary Daniell, however, is by no means suitable as a standard, because of the diffusion of the copper-liquid through the porous cell. This defect must obtain in any cell where two liquids separated by a porous partition are employed; and hence attempts have been made to construct standard cells with solid electrolytes, or with mercury instead of copper salts, as in the little cell devised by Mr. Latimer Clark, which, though not absolutely constant, is still, I suppose, the best for its special purpose. But all cells with solid electrolytes are extremely inconstant, in the sense that they suffer greatly from shortcircuiting and take some time to recover themselves; and there are some other inconveniences attending the use of a large number of Clark's cells.
\end{abstract}

A convenient Daniell Cell with high internal Resistance.

Of all known cells, a Daniell charged with sulphate of zinc and sulphate of copper seems to be the most perfect-in this

- Communicated by the Phrsical Society-one of the cells having been exhibited at a meeting of the Society in February 1877.

Phil. Mag. S. 5. Vol. 5. No. 28. Jan. 1878. 
respect, that the materials remain always the same during action except that the sulphate of zinc gradually increases in quantity, a difference which scarcely affects the electromotive force. Almost the only defect in the constancy of a cell so charged is due to the fact that the two liquids diffuse into each other, for which reason the battery cannot retain its original state after it has stood for some time. Any thing equivalent to a porous partition is quite useless for keeping the liquids separate; and the only plan seems to be to provide as long a culumn of liquid as possible for the copper salt to diffuse through.

This is done in a compact and simple manner in the cell represented in fig. 1 (Pl. I.). A wide-mouthed bottle (or a tall jar) is fitted with a cork through which passes a wide glass tube open at both ends. To the lower end of this tube a short closed tube (like a test-tube) is tied with silk thread; a long strip of sheet zinc is put down the open tube; and a copper wire, recurved at the bottom and coated with sealing-wax except at its two ends, is passed through the cork to the bottom of the closed tube, where it is imbedded in a few crystals of copper sulphate. The bottle is then nearly filled with dilute sulphate of zinc, and the cork with the tube is inserted, the latter being so arranged that the end of the zinc strip and the mouth of the short tube are both below the surface of the liquid. In a short time a strong solution of sulphate of copper forms at the bottom of the closed tube where the copper wire is bare, and it gradually diffuses upward; but in order to reach the zinc it has to diffuse itself all through the water of the bottle and then up the long tube containing the zinc; and this takes a long time, though it certainly does take place to some extent in a week or so.

But when I want to put the cell by for any length of time, I pull the long tube a little higher up through the cork, so that the mouth of the short tube emerges above the liquid and thus ontirely prevents diffusion. The zinc strip is also raised out of the liquid by the same action. It is convenient to have the cork fitting pretty air-tight; or else evaporation may go on from the edges of the tube, and the salts which crystallize there may continue the diffusion slowly.

The copper wire need not be covered with wax or any thing; but if it were not, its upper parts would assist in the action until they were polarized; and hence the internal resistance would be liable to vary, which is not desirable. The internal resistance of such a cell is always rather high: for instance, in the one of which fig. 1 is a portrait, the bottle stands about 6 inches high, and the internal resistance is about $500 \mathrm{ohms}$ 

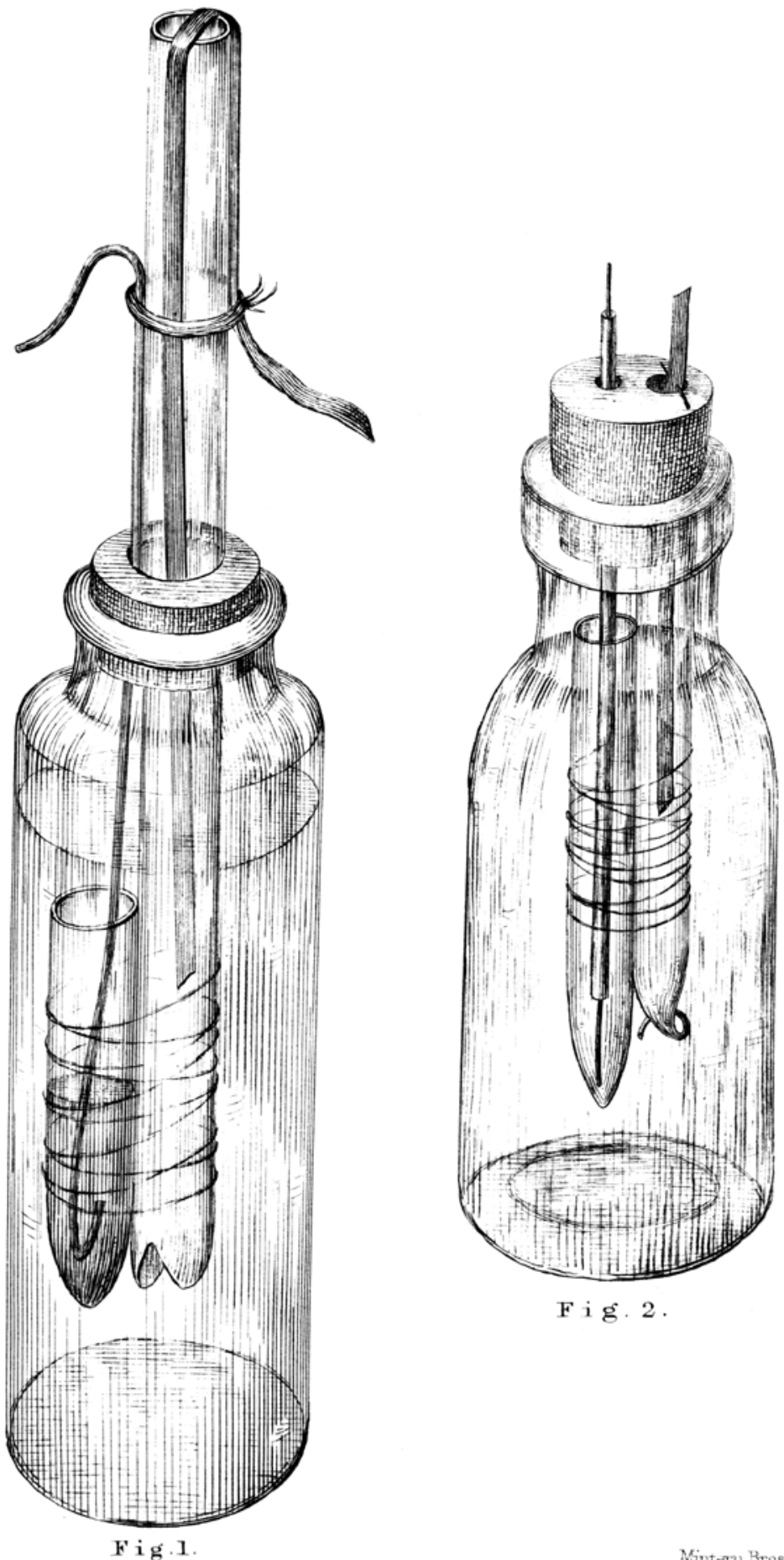
when arranged as shown ; but of course it depends greatly on the position of the tubes, and also somewhat on the temperature. Hence it is not to be regarded as giving necessarily a very constant current, but rather as a cell which can be used for a long time and yet keep its electromotive force nearly unchanged.

I have also made a set of small cells on the same principle, with ordinary quilled tubing for the tubes, and with test-tubes for the containing vessels, making the connexions by twisting the thin copper wire of one cell round the projecting tube (with the zine bent down springily over it) of the next. A large number of such cells may be quickly made and arranged in ordinary test-tube stands; and they are convenient for many purposes, such as capacity- or insulation-testing, where high electromotive force is required *. The whole rack of cells was once accidentally upset; but though a little liquid escaped from the open ends of the zinc-tubes, the copper-liquid remained steady at the bottom of its tube without visible disturbance.

\section{A Cell for a Standard of Electromotive Force.}

Fig. 2 shows a bottle about 3 inches high, which I have made to act as a standard of electromotive force. It differs in no essential respect from fig. 1, except that the mouth of the tube containing the copper-solution never dips below the surface of the liquid, but always projects $\frac{1}{4}$ inch above it. The other or open tube does not project at all above the cork; and its lower end is drawn out and coiled round so as still further to retard the passage of the copper-liquid to the zinc. The zinc, which should be pure, is supported at the right height by a pin thrust through it. The closed tube is proportionally longer than in fig. 1 ; it is nearly filled with pure sulphate-ofcopper solution, a few crystals being placed at the bottom; and it is tied to the other tube, as before, with silk thread (which appears not to rot). The copper wire is gutta-perchacovered with its ends bared. The bottle is filled nearly to its neck with very dilute sulphate of zinc; and the cork is then inserted air-tight.

No mixing of the liquids is now possible; but conduction still takes place over the damp surface of the glass tube, especially if, before use, the whole bottle be slightly inclined so as to wet the edges of the tube. The slight film of zinc-salt thus formed, being hygroscopic and being in a saturated atmo-

* I suppose that by using platinum instead of copper wire, and strong nitric acid or else sulphuric acid and bichromate of potash instead of the copper salt, one could nearly double the electromotive force, though with some loss of constancy. 


\section{Sir W. Thomson on the Thermoelastic, Thermomagnetic,}

sphere, will keep the top of the tube sufficiently moist for an immense time.

The only possible changes which can go on in this cell are in the zinc and the solution in immediate contact with it. This solution can at any time be drawn off with a pipette and replaced by fresh, without greatly affecting the liquid in the bottle (if the cork be air-tight); and the zine can still more easily be taken out and replaced by a new piece.

I have described the cell as at present made; but if there were any chance of its coming into use as a standard, a few modifications might be introduced. Thus the zine might be a short rod with an india-rubber collar fitting the tube and with a short copper wire attached to it, which should project above the cork instead of the zinc, the joint being a little way down the tube and protected by a coat of varnish from damp air. A set of experiments would have to be made to determine the dependence of electromotive force on temperature; and then a thermometer with a short scale might be fixed in each cork.

University College, London.

II. Cn the Thermoelastic, Thermomagnetic, and Pyroelectric Preperties of Matter. By William Thomson, M.A., late Fellow of St. Peter's College, Cambridge, Professor of $\mathrm{Na}$ tural Philosophy in the University of Glasgow*.

1. A BODY which is either emitting heat, or altering its A dimensions against resisting forces, is doing work upon matter external to it. The mechanical effect of this work in

* LThis paper is in the main a reprint from an article which appeared under the title "On the Thermoelastic and Thermomagnetic Properties of Matter, Part I.," in A pril 1855, in the first nunber of the "Quarterly Journal of Mathtmatics', but which was confined to the thermoelastic part of the subject. The continuation, in which it was intended to make a similar application of thermodynamic principles to magnetic induction, was never published or written; but the results which it should have contained were sufficiently indicated in a short article on "Thermomagnetism," which I wrote at the request of my friend and colleague the late Professor J. P. Nichol for the second edition of his 'Cyclopedia,' published in 1860, and which I include in the present reprint. The addition of "Pyro-Electricity" which I now make to the title of the former article, is justified by another short quotation from the second edition of Nichol's 'Cyclopædia' (article "Thermo-Electricity, Division I.-- Pyro-Electricity, or Thermo-Electricity of Nonconducting Orystals"), and a short addition, now written and published for the first time, in which the same thermodynamic principles are applied to this form of thermoelectric action.

Several additions both in the shape of text and footnote are appended in the course of the reprint. These are all distinguished by being enclosed in brackets, [ ].] 